\title{
The Role of Transposable Elements in Health and Diseases of the Central Nervous System
}

\author{
Matthew T. Reilly, ${ }^{1}$ Geoffrey J. Faulkner, ${ }^{2}$ Joshua Dubnau, ${ }^{3}$ Igor Ponomarev, ${ }^{4}$ and Fred H. Gage ${ }^{5}$ \\ ${ }^{1}$ National Institute on Alcohol Abuse \& Alcoholism, Bethesda, Maryland 20892, ${ }^{2}$ Mater Medical Research Institute, South Brisbane Queensland, Australia, \\ $4101,{ }^{3}$ Cold Spring Harbor Laboratory, Cold Spring Harbor, New York 11724, ${ }^{4}$ University of Texas at Austin, Waggoner Center for Alcohol \& Addiction \\ Research and the College of Pharmacy, Austin, Texas 78712, and ${ }^{5}$ The Salk Institute, Laboratory of Genetics, La Jolla, California 92037
}

First discovered in maize by Barbara McClintock in the 1940s, transposable elements (TEs) are DNA sequences that in some cases have the ability to move along chromosomes or "transpose" in the genome. This revolutionary finding was initially met with resistance by the scientific community and viewed by some as heretical. A large body of knowledge has accumulated over the last 60 years on the biology of TEs. Indeed, it is now known that TEs can generate genomic instability and reconfigure gene expression networks both in the germline and somatic cells. This review highlights recent findings on the role of TEs in health and diseases of the CNS, which were presented at the 2013 Society for Neuroscience meeting. The work of the speakers in this symposium shows that TEs are expressed and active in the brain, challenging the dogma that neuronal genomes are static and revealing that they are susceptible to somatic genomic alterations. These new findings on TE expression and function in the CNS have major implications for understanding the neuroplasticity of the brain, which could hypothetically have a role in shaping individual behavior and contribute to vulnerability to disease.

\section{Introduction}

Almost half of mammalian genomes are comprised of a class of repeat DNA sequences known as transposable elements (TEs) (Lander et al., 2001), where some TEs have the ability to mobilize and change locations in the genome. Other eukaryotes contain substantial proportions of TEs, making TEs a general feature of genomes across many organisms (Adams et al., 2000; Waterston et al., 2002; Gibbs et al., 2004; Nellaker et al., 2012). Yet, their roles in human health and disease and in genomic evolution are not well defined. Once considered "junk" or "selfish" DNA, TEs are now being appreciated for their specific functional roles in a variety of biological phenomena that can be both beneficial and pathological to the organism (Biémont, 2010). Barbara McClintock, who is credited with the discovery of TEs, first proposed two main functions: (1) insertional mutagens and (2) "controlling elements" that regulate the expression of nearby genes. McClintock's findings were not well accepted at the time of publication of her seminal work (McClintock, 1951). A large body of knowledge has accumulated over the last 60 years on TE biology (Britten and Kohne, 1968; Grimaldi and Singer, 1982;

\footnotetext{
Received Aug. 6, 2013; revised Sept. 11, 2013; accepted Sept. 11, 2013.

G.J.F. was supported by Australian National Health and Medical Research Council Project Grants GNT1042449and GNT1045991 and Career Development Fellowship GNT1045237. J.D. was supported by National Institutes of Health Grant R01NS067690 and DART Neuroscience LLC. I.P. was supported by National Institutes of Health Grants AA013517, AA013476, and AA017234, and a DoD-TATRC Grant. F.H.G. was supported by National Institutes of Health Grants R01MH088485 and R01 MH095741 and the G. Harold \& Leila Y. Mathers Foundation. We thank M.L. Gage for editorial comments on the manuscript.

The authors declare no competing financial interests.

Correspondence should be addressed to either of the following: Dr. Matthew T. Reilly, National Institute on Alcohol Abuse and Alcoholism, National Institutes of Health, MSC 9304, Bethesda, MD 20892, E-mail: reillymt@mail.nih.gov; or Dr. Fred H. Gage, The Salk Institute, Laboratory of Genetics, 10010 N Torrey Pines Road, La Jolla, CA 92037-1099, E-mail: gage@salk.edu.

DOI:10.1523/JNEUROSCI.3369-13.2013

Copyright $\odot 2013$ the authors $\quad 0270-6474 / 13 / 3317577-10 \$ 15.00 / 0$
}

Boeke et al., 1985; Daniels and Deininger, 1985; Kazazian et al., 1988; Xiong and Eickbush, 1988b; Britten et al., 1989; Dombroski et al., 1991; Batzer et al., 1996; Moran et al., 1999). For example, Kazazian et al. (1988) discovered that hemophilia A resulted from a de novo insertion of a TE. This study was one of the first to demonstrate that a TE insertion in the human genome caused disease (Kazazian et al., 1988). However, a new interest in the function of TEs has resulted in part from large-scale genomic projects, such as the ENCyclopedia Of DNA Elements (ENCODE) and Functional Annotation of Mouse (FANTOM) projects. These studies showed that TEs are active in a highly cell type-specific manner and control their own cell-specific transcription as well as the transcription of neighboring genes (Faulkner et al., 2009; Djebali et al., 2012; Thurman et al., 2012). Finally, the advent of next-generation whole-genome sequencing approaches has identified major structural variation resulting from TE activity (Beck et al., 2010; Ewing and Kazazian, 2010; Huang et al., 2010; Iskow et al., 2010).

There are two major classes of TEs, distinguished by their mechanism of transposition (Levin and Moran, 2011). DNA transposons move via a cut-and-paste mechanism and are generally thought to be extinct in higher eukaryotes. Therefore, DNA transposons will not be discussed further in this review. However, RNA transposons (herein called retrotransposons or mobile elements) move via a copy-and-paste mechanism using RNA as an intermediate. Retrotransposons, namely, Long-Interspersed Elements (LINE1s), are the only known active and autonomous elements in the human genome (Beck et al., 2011). Other retrotransposon families include: Short-INterspersed Elements (SINEs), Alu and SVA elements. Retrotransposons with a long terminal repeat (LTR), such as endogenous retroviruses (ERVs), are also present in the human genome, but evidence has yet to be 
shown that ERVs have the ability to move (Moyes et al., 2007). Retrotransposition-mediated events in mammals are not only confined to germ cells, as once thought, but can produce somatic alterations in the brain and cancer (Muotri et al., 2005; Baillie et al., 2011; Solyom et al., 2012). That retrotransposons can generate neuronal somatic mosaics (Singer et al., 2010), creating genetic heterogeneity across neurons in the same individual, has wide-reaching implications for all areas of neuroscience (Muotri et al., 2005; Baillie et al., 2011; Perrat et al., 2013).

This review focuses on the recent identification of CNSspecific retrotransposons as generators of genetic heterogeneity, their regulation and function, and their role in health and diseases of the brain (Thomas et al., 2012). Many challenges remain, but new technologies for retrotransposon capture sequencing (Baillie et al., 2011) and single-cell TE analysis (Evrony et al., 2012) are opening up novel areas for discovery. However, retrotransposons may play a role in neurogenesis (Muotri et al., 2005; Coufal et al., 2009; Muotri et al., 2010), aging (Li et al., 2013), neurodegenerative diseases ( $\mathrm{Li}$ et al., 2012), alcoholism (Ponomarev et al., 2012), and post-traumatic stress disorder (PTSD) (Ponomarev et al., 2010). The latest findings in these areas will be presented in a symposium at the annual Society for Neuroscience meeting in 2013.

\section{Mobile elements, neuronal mosaicism, and evolution}

Each cell in the body contains DNA, which instructs the cell and tissues to perform specific functions through the transcription of mRNA and translation of proteins. The DNA sequence within the nucleus has long been thought to be identical across different cell types within an individual, with the exception of the gene rearrangements in the immune system and in some cancer cells. The finding that L1 retrotransposons are active in somatic cells and have structural and functional consequences in neuronal genomes challenges the dogma that neurons are genetically stable entities (Muotri et al., 2005; Coufal et al., 2009; Baillie et al., 2011; Evrony et al., 2012; Perrat et al., 2013). The consequences of L1 activity in neurons resulting in neuronal mosaicism are evident throughout embryo development and in the adult brain (Thomas et al., 2012). This novel mechanism may contribute to genomic neuronal diversity across neurons in the same individual: the "one human, multiple genomes" phenomenon that has been demonstrated in a number of different cell types (Lupski, 2013). These findings on somatic retrotransposition in the brain offer a new paradigm to understand the unexplained variation seen in many psychiatric disorders that has evaded detection by conventional methods, such as genome-wide association studies (Manolio et al., 2009). Perhaps more generally important is the role of mobile elements in evolution, where they can be characterized as having a constructive role in genomic innovation rather than just being another random source of genetic variation (Heard et al., 2010).

L1s are one of the most ancient and successful innovations in eukaryotic genomes, comprising $\sim 20 \%$ of mammalian genomes (Lander et al., 2001; Waterston et al., 2002; Gibbs et al., 2004; Nellaker et al., 2012). Active human L1s are $\sim 6 \mathrm{~kb}$ long, harbor an internal polymerase II promoter, and encode two open reading frames (ORFs) (an RNA chaperone protein, ORF1, and an endonuclease and reverse transcriptase protein, ORF2), usually ending with a polyadenylic acid or short A-rich tail. They are the only autonomous transposable element known in the presentday human genome, encoding the essential machinery required to move within the genome. Upon translation, the L1 RNA assembles with its own encoded proteins (cis-preference) (Wei et al., 2001; Dewannieux et al., 2003) and moves to the nucleus, where an endonuclease makes a single-stranded nick and the reverse transcriptase uses the nicked DNA to prime reverse transcription from the $3^{\prime}$ end of the L1 RNA. L1-encoded proteins also provide the machinery to mobilize (in trans) nonautonomous retrotransposons (e.g., Alu and SVA elements) and other mRNAs that generate processed pseudogenes (Esnault et al., 2000; Wei et al., 2001; Kajikawa and Okada, 2002; Dewannieux et al., 2003; Hancks et al., 2012; Raiz et al., 2012). Reverse transcription frequently fails to proceed to the $5^{\prime}$ end, resulting in mainly truncated, nonfunctional de novo insertions. In addition, epigenetic and post-transcriptional silencing mechanisms exist to repress mobilization in somatic cells (Whitelaw and Martin, 2001; Slotkin and Martienssen, 2007; Chung et al., 2008; Czech et al., 2008; Ghildiyal et al., 2008; Kawamura et al., 2008; Garcia-Perez et al., 2010). However, there is evidence that some L1 insertions are functional. Human L1s structurally resemble those present in rodent and even invertebrate genomes, and a cultured cell retrotransposition assay has revealed that human L1s can retrotranspose in a variety of mammalian, nonhuman cell lines (Moran et al., 1996; Coufal et al., 2009).

Based on reverse transcriptase phylogeny, L1 elements are most closely related to the group II introns of mitochondria and eubacteria (Xiong and Eickbush, 1990; Cavalier-Smith, 1991). These studies revealed that the reverse transcriptase enzyme is extremely old and that retroelements can be viewed as relics or molecular fossils of the first primitive replication systems in the progenote. The origin of retroelements possibly traces back to the conversion of RNA-based systems, the "RNA World," to modern "DNA-based" systems. Current models suggest that these mobile introns of eubacteria were transmitted to eukaryotes during the initial fusion of the eubacterial and archaebacterial genomes or during the symbiosis that gave rise to the mitochondria, generating the modern-day spliceosomal introns (Zimmerly et al., 1995). Further acquisition of an endonuclease enzyme and a promoter sequence represented important steps in the evolution of L1 retrotransposons, providing autonomy for L1s to insert into many locations throughout the genome and provide the molecular machinery for mobilization of nonautonomous elements.

The apparent lack of function of retroelements in the genome has long puzzled scientists and inspired the concept of "junk DNA" to illustrate the idea that such sequences are mere evolutionary remnants (Ohno, 1972). However, the recognition that retrotransposons can actively reshape the genome is slowly challenging this terminology. Moreover, the mammalian genome has suffered waves of transposon bombardment, but the constant, single lineage of L1 history reveals that active, retrotranspositioncompetent L1 sequences were never absent from mammals' genomes during evolution, suggesting an inextricable link between L1s and their hosts (Levin and Moran, 2011). The relationship between transposons and their hosts is probably not entirely antagonistic, as several host genes have a high degree of homology to one or more transposable elements. For example, the sequence of paired box gene 6 (PAX6), a DNA-binding protein that regulates transcription, is derived from a transposase (Feschotte, 2008). In addition, the telomerase enzyme, responsible in most mammals for replication of the ends of chromosomes, is derived from retrotransposons (Nakamura and Cech, 1998). As described above, accumulating recent evidence in the literature points to a somatic function for L1 transcripts, involving cell proliferation, differentiation, and embryo development, although it is unclear how these different retrotransposons may be acting. Moreover, it is difficult to determine why the genome would need so many cop- 
ies of retrotransposons and whether this expansion has any correlation with retrotransposition itself. The lack of an "apparent" cell function suggests that transposable elements are "selfish DNA," acting as parasites in the genome to propagate themselves (Orgel and Crick, 1980). The restricted activity of retrotransposons in germ or early embryonic cells apparently fits well with this concept because new insertions will be passed to the next generation. However, somatic insertions pose a conundrum because they will not be transmitted to the next generation. According to the symbiotic theory, it is advantageous to any transposable element to promote host mating, securing the propagation of the "master" elements to the next generation. From this perspective, it would not be surprising if advantageous insertional events in the brain, resulting in a better (cultural and social) fitness of the individual organism, also contributed to host mating. For example, Barsoum et al. (2010) showed that a transposable element promotes host sexual reproduction. This is the first empirical evidence of an association between a transposable element and sexual reproduction (Barsoum et al., 2010), which is congruent with a theoretical model proposed by Hickey (1982). Such a model requires the mechanism that allows retrotransposition in somatic cells to be similar to the mechanism existing in germ cells (i.e., that the factors involved in L1 mobilization in germ cells be related to the factors acting in the brain). Indeed, in silico data reported similarities between human brain and testes gene expression patterns (Guo et al., 2003, 2005). It has been proposed that the similarities in expression in human brain and testes may have very important implications for human speciation (Wilda et al., 2000; Graves, 2010). The emergence of new species during evolution might be the result of coordinated changes in many organ systems, and the organs associated with evolution would share a common set of regulatory genes. Although it has been proposed that genes in the Sox family in testes and brain share the same genetic origins, it seems unlikely that all other factors involved in L1 transcription would behave in the same way, contributing to the obvious differences observed in these two tissues. Although the role of transposable elements in human speciation and the hypothesis that the brain and reproductive organs coordinate this process are still highly speculative, the characterization of factors involved in the L1 retrotransposition in germ and brain cells will provide further insights into the evolution of these two organs.

If new L1 insertions in the brain are not passed to future generations, why would evolution conserve such a mechanism in the nervous system? Our hypothesis is that it is the propensity for L1 mobilization, rather than its consequences, on which natural selection may apply (Upton et al., 2011). Somatic retrotransposition may lead to the evolution of functional de novo regulatory elements more rapidly than by random accumulation of point mutations (Mukamel and Tanay, 2013), creating a greater potential for adaptation of beneficial genetic networks. As mentioned above, epigenetic modifications, particularly DNA methylation of CpG dinucletodies, are mechanisms used to suppress L1 mobilization. These potentially heritable epigenetic modifications may suppress deleterious L1 insertions, providing a buffer to allow further adaptation of $\mathrm{L} 1$ regulatory elements for the benefit of the host (Xie et al., 2013). This hypothesis is certainly speculative but might gain support by studying our own species. The human species has an enormous spectrum of phenotypic variation, despite being genetically quite homogeneous (Lander et al., 2001; Witherspoon et al., 2007; Henn et al., 2012). It has been proposed that a major portion of biological complexity in hu- mans arises from regulation of the genome by the non-protein coding regions (e.g., epigenetic modifications and noncoding RNAs) (Carroll, 2008; Mattick et al., 2010). The diversity of behaviors, cultural practices, and languages that are not biologically inherited but have biological origins may have been important to control new resources or inhospitable territories. At the individual level, humans are also very diverse. Such variation can even be found in genetically identical twins. Recent studies have pointed to epigenetic variations during the life of monozygotic twins (Fraga et al., 2005). However, the idea that epigenetic modifications underlie many of the cognitive and sociobehavioral traits in humans is still highly speculative. The evolution of the CNS provided a notable selective advantage, as information about the environment could be processed rapidly and would allow organisms to more readily meet the challenges of ever-changing environmental conditions. Moreover, epigenetic modification allowed the nongenetic transfer of information or transmission of "culture" at an unprecedented magnitude (Jablonka and Lamb, 2007). Such specialization is highly dependent on the cognition levels acquired by the species, and cognitive levels are directly linked to the complexity of the neuronal network. Therefore, the advantages gained by retaining the mechanisms for somatic retrotransposition may outweigh the cost of a less plastic nervous system. We think that $\mathrm{L} 1$ retrotransposition may be part of a conserved core process responsible for generating genetic variability within germ and neural genomes. That is, the core molecular processes controlling L1 retrotransposition are conserved across organs (e.g., brain and testis) but result in different phenotypic cellular traits because of retrotransposition at varying loci, a principle known as pleiotropy (Wagner and Zhang, 2011). Such a process could evoke a facilitated, complex, nonrandom phenotypical variation on which selection would act. Therefore, transposable elements may play a constructive role in evolution and organogensis, where transposable elements could be coopted by their host as cis-regulatory elements and direct novel patterns of gene expression (Emera and Wagner, 2012; Wanichnopparat et al., 2013).

\section{Techniques for mapping retrotransposons in the brain}

The frequency, developmental timing, and functional consequences of endogenous L1 retrotransposition in the mammalian brain remain largely unclear. Until recently, experimental evidence supporting neuronal L1 activity was primarily supplied by (1) engineered L1 reporter assays, measuring mobilization of an EGFP tagged L1 (L1-EGFP) in vitro and in vivo (Ostertag et al., 2000; Muotri et al., 2005, 2009; Coufal et al., 2009), and (2) L1 copy number variation (CNV) assays based on TaqMan qPCR of genomic DNA extracted from human tissue (Coufal et al., 2009). These approaches enabled the laboratory of F.H.G. and others to make the seminal observation that L1 activation occurs in neuronal precursor cells and produces L1 CNV in the human body, enriched in the brain (Muotri et al., 2005; Coufal et al., 2009). Critically, in vivo 3D modeling using a transgenic L1-EGFP mouse revealed few GFP-positive clusters $>1-2$ cells, suggesting that most L1 activity occurred late in neuronal differentiation (Muotri et al., 2010). This view was reinforced by the finding that mouse and human neuronal precursor cells deficient for the L1 promoter repressor $\mathrm{MeCP} 2$ exhibited higher L1-EGFP activity and L1 CNV than wild-type controls (Muotri et al., 2010). Together, these data highlighted a highly complex somatic genome mosaic in the brain (Singer et al., 2010), driven by L1 and with an apparent enrichment for the subgranular zone of the hippocampus, an established neurogenic niche (Eriksson et al., 1998). 
Despite yielding intriguing and consistent data, several drawbacks are apparent for the L1-EGFP and L1 CNV assays. For instance, as an engineered system, epigenetic regulation of the L1-EGFP system may not exactly recapitulate regulation of endogenous L1s in vivo, potentially overstating their activity. Conversely, the addition of a $1.2 \mathrm{~kb}$ GFP reporter construct at the $3^{\prime}$ end of a tagged L1 element (Ostertag et al., 2000) may understate L1 activity in situations where L1 reverse transcription extends for $<1.2 \mathrm{~kb}$ at a given integration site. Absolute quantification of L1 mobilization per cell using the L1 CNV assay, an approach that has indicated up to 80 somatic L1 copies per human neuron (Coufal et al., 2009), is confounded by the need to perform a plasmid "spike-in" as a reference control. It is also a possibility that L1 reverse transcription occurs in cytoplasmic foci without genomic integration. Thus, although these techniques provoked the key hypothesis that L1 mobilization occurred in neuronal precursor cells, more direct approaches, such as high-throughput sequencing, were required to precisely establish how often L1 mobilized during neurogenesis and, just as importantly, to determine which loci contained new L1 insertions.

Genomic mapping of somatic L1 variants in the brain is confounded by (1) high L1 copy number in genomic DNA (>500,000 L1 copies in the human reference sequence) and (2) the projected rarity of each individual L1 insertion. One way to overcome these issues is to perform targeted, deep sequencing of L1 integration sites. For instance, retrotransposon capture sequencing (RC-seq), an L1 mapping strategy based on sequence capture enrichment of L1 $5^{\prime}$ and $3^{\prime}$ genomic junctions and applied to hippocampus and caudate samples from three individuals, reported several thousand somatic L1 insertions (Baillie et al., 2011). These occurred primarily in hippocampus, a trend strongly correlated with L1 CNV assay data obtained from the same samples (Baillie et al., 2011). Other approaches developed to study Drosophila transposable elements detected endogenous retrotransposition in purified neurons, with whole-genome sequencing (Perrat et al., 2013) and in vivo with a gypsy-TRAP reporter (Li et al., 2013), suggesting that a range of underexplored methodological options may yet be made available to study L1 mobilization in "bulk" human tissue samples.

However, the recent invention of single-cell genomic analysis techniques will likely prove decisive in counting somatic L1 insertions in neurons. In a recent landmark publication, Evrony et al. (2012) presented L1 mapping data from single neurons, using whole-genome amplification followed by targeted L1 sequencing. A total of 300 single neurons from the caudate and cerebral cortex were obtained from three normal individuals. Ninety-six candidate somatic L1 insertions were identified. Most of these candidates were deemed false positives after validation assays. However, one candidate somatic L1 insertion was successfully cloned. A full-length $6.1 \mathrm{kB} \mathrm{L1}$ sequence was confirmed that contained all the characteristics of a retrotransposon: a target site duplication (TSD), a poly-A tail, and a $5^{\prime}$ transduction sequence. Four additional L1 insertions were validated by insertion site PCR at their $3^{\prime}$ end, but target site duplications could not be identified. Crucially, this was the first report of a validated somatic L1 insertion presenting TSDs in a human neuron, perhaps the best evidence presented thus far that L1 mobilization can occur in the brain.

The L1 mobilization rate reported by Evrony et al. (2012), perhaps as low as 1 in 300 neurons, contrasts with earlier calculations based on the L1 CNV assay (Coufal et al., 2009). It is, however, important to note that Evrony et al. (2012) did not evaluate hippocampal neurons, whereas other groups had previ- ously reported major enrichment in this region (Coufal et al., 2009; Baillie et al., 2011), making it difficult to determine whether the discrepancy in L1 mobilization frequency estimates is the result of technical or brain regional differences. In addition, because brain samples in the studies of Baillie et al. (2011) and Evrony et al. (2012) were obtained from different individuals, biological variability could explain the discrepancies in L1 mobilization rate. That is, there may be biological heterogeneity in the rate of L1 mobilization across different populations of individuals. Further, because a range of environmental factors, including stress (Ponomarev et al., 2010; Hunter et al., 2012), alcohol (Ponomarev et al., 2012), and exercise (Muotri et al., 2009), can alter retrotransposon expression, variation in environmental exposures across individuals may contribute to the differences reported in the two studies. In any case, it is important to note that the adult human brain contains $\sim 86$ billion neurons (Azevedo et al., 2009). Based on the lower estimate of 1 new L1 insertion per 300 neurons, an extrapolation suggests that nearly 300 million distinct somatic L1 insertions would be found per brain. Therefore, even if lower estimates of new L1 insertions are correct, somatic retrotransposition could still potentially have a dramatic effect on the function of neurons.

Although others have found brain-specific L1 insertions to be enriched in genes involved in neurogenesis, even when correction for the unusual size of these genes was performed (Baillie et al., 2011), it remains unclear whether these mutations alter the function of the affected neurons. Moreover, although the full-length somatic L1 insertion found by Evrony et al. (2012) occurred in an intron of IQCH, a gene expressed in the brain, it was not determined whether host gene expression was perturbed. Future experiments guided by recent technical innovations are required to corroborate and build upon the two major reports of L1 mapping in the human brain published to date (Baillie et al., 2011; Evrony et al., 2012).

\section{The transposon storm: from Barbara McClintock to Lou Gehrig}

Barbara McClintock's dissociator and activator transposons explained unstable cellular inheritance of pigmentation patterns in maize (McClintock, 1951, 1984). McClintock referred to these transposons as "controlling elements" because their mobilization impacted the expression of nearby genes. Thus, even in McClintock's original work nearly 60 years ago, the potential for transposons to shape phenotypic outcomes was apparent, challenging the prevailing view that transposons were mere selfish DNA (Orgel and Crick, 1980). On the other hand, the unregulated activation of transposons, as seen for example with dysgenic crosses, reveals the powerful harmful impact of unregulated mobile elements (Pignatelli and Mackay, 1989; Jensen et al., 1995, 1999; Malone and Hannon, 2009). Indeed, animals and plants have evolved formidable surveillance mechanisms to detect and eliminate expression of transposons both in germline and somatic cells (Ghildiyal and Zamore, 2009; Czech and Hannon, 2011). The discovery that some transposable elements are actively mobile in brain (Muotri et al., 2005, 2010; Coufal et al., 2009; Baillie et al., 2011; Evrony et al., 2012; Perrat et al., 2013) thus raises two potential possibilities. The first, discussed above, is the notion that insertion of transposable elements may exert a controlling influence on flanking genes, causing a functionally relevant impact on the diversification of neuronal cell types or on the function of differentiated neurons. At the same time, however, we must consider the potential detrimental impact of unregulated transposon expression. 
Transcripts from several Drosophila retrotransposons, such as R1 and R2 (which are LINE-like elements) and Gypsy (an LTRretrotransposon), become highly expressed in head tissue during the course of normal aging (Li et al., 2013). In the case of Gypsy, a monoclonal antibody against the third Orf, which encodes the Env protein, also reveals a striking age-dependent accumulation of Env-immunoreactive puncta throughout neuropil and the "cortical" regions of the fly brain, which contain most of the neuronal and glial somata. In addition, age-dependent expression of Gypsy is associated with accumulation of de novo transposition events in neurons. This association was revealed using a "Gypsy-trap" reporter system in which a genomic hotspot for Gypsy integrations was incorporated into a transgenic construct such that insertions of Gypsy would inactivate expression of a Gal80 repressor (Li et al., 2013). Gypsy insertions thus turns off the repressor, allowing Gal4-mediated expression of a GFP reporter. This Gypsy-trap reporter revealed an apparently stochastic and sparse labeling of neurons that accumulated with advancing age.

In broad strokes, the finding that certain retrotransposons are active and even mobile in brain during aging is parsimonious with the observed mobility of L1s during mammalian neurogenesis (Muotri et al., 2005; Baillie et al., 2011) and of a number of transposable elements during Drosophila neurodevelopment (Perrat et al., 2013). On the other hand, the age-dependent increase in transposition in Drosophila brain that takes place after development is almost certainly occurring in terminally differentiated neurons because adult neurogenesis has not been seen in Drosophila. Thus, the observed age-dependent activation is mechanistically distinct from the transposition that normally occurs during development and neurogenesis. And, in contrast with the potential for a functionally relevant impact on normal neurophysiology with transposition during neurogenesis, two features of the age-dependent activation suggest detrimental consequences. First is the fact that both R1 and R2, unlike most LINE-like elements, exhibit target specificity in the genome. Both of these elements target unique locations within the 28s subunit of rRNA (Xiong and Eickbush, 1988a; Eickbush et al., 1997; Moss et al., 2011). In the case of R2, almost all insertions occur at the $28 \mathrm{~s}$ target site. Thus, unlike LINE 1 elements in mammals, R1 and R2 seem less likely to produce genetic heterogeneity that could functionally diversify neuronal physiology in a meaningful way. Because insertion of either of these elements is sufficient to inactivate the rRNA subunit, the accumulation of de novo insertions of R1 or R2 during aging would seem likely to have detrimental rather than beneficial consequences. A second observation that suggests disruptive effects is the time course of transposon activation. The expression of R1, R2, and Gypsy and the accumulation of de novo Gypsy insertions each begin in 2- to 4-week-old adults (Li et al., 2013), which is relatively late in the life span of Drosophila. Thus, the time course of transposon activation in the adult Drosophila brain is more consistent with an impact on age-related decline than on normal function.

However, there are cases where transposon activation in Drosophila is not purely antagonistic or detrimental to the organism. For example, non-LTR retrotransposons have been recruited to serve a telomerase function in Drosophila, which maintains genomic integrity (Zhang and Rong, 2012). Nonetheless, transposon activation in the germline has documented detrimental consequences for a number of reasons, including genomic instability, accumulation of deleterious mutations, toxic accumulation of protein or RNA products, and activation of DNA-damage induced apoptosis (Tanda and Corces, 1991; Sheen et al., 1993;
Houle and Nuzhdin, 2004; Navarro et al., 2009). Two sets of findings provide indirect evidence that age-dependent activation of transposons in brain does indeed have a detrimental impact. The first comes from manipulations of the Chk2 signal that normally results in apoptosis after DNA damage and the second from disruption of Drosophila argonaute-2 (Chen et al., 2007; Klattenhoff et al., 2007; Chung et al., 2008; Czech et al., 2008; Ghildiyal et al., 2008; Kawamura et al., 2008).

The negative consequences of DNA damage resulting from transposon activation have been established in the germline. Paradoxically, blocking the DNA damage-induced signaling that normally leads to apoptosis can in some situations ameliorate the destructive effects of transposon activation in the germline. Disruption of Chk2-mediated signaling of DNA damage "tricks" cells into staying alive and actually suppresses the sterility caused by transposons (Chen et al., 2007; Klattenhoff et al., 2007). This same "trick" appears to ameliorate some of the effects of age in Drosophila, where disruption of the Chk2 ortholog in neurons is sufficient to extend life span (Li et al., 2013). Although the connection between the functional effects of disrupting Chk 2 and retrotransposons is indirect, it is tempting to speculate that transposon activation contributes to age-dependent neurophysiological decline in part by induction of DNA damage leading to apoptosis.

A second line of evidence that is consistent with the interpretation that age-dependent transposon activation in brain is detrimental comes from manipulation of the Drosophila argonaute- 2 gene. Argonaute proteins are guided by small regulatory RNAs to silence transposons that contain complementary sequences (Ghildiyal and Zamore, 2009; Czech and Hannon, 2011). In Drosophila, this cellular immunity against transposons in germline versus somatic tissue relies on different argonaute proteins that load distinct pools of small RNAs. Silencing of transposons in somatic tissues, but not germline, requires the Drosophila argonaute-2 gene (Chung et al., 2008; Czech et al., 2008; Ghildiyal et al., 2008; Kawamura et al., 2008). Thus, mutation of argonaute- 2 in flies provides a means to unleash transposons in somatic tissues independent of age. Such mutations indeed lead to precocious expression of R1, R2, and Gypsy in young brains to levels normally seen only in older animals ( $\mathrm{Li}$ et al., 2013). This expression is accompanied by rapid agedependent memory impairment and shortened life span. Thus in flies, transposon activation appears to accompany normal aging, and precocious activation of these transposons correlates with more rapid neurophysiological decline. Such functional studies of transposon activation in mammalian brain during aging have not been reported, but there are a few lines of evidence that mobile elements may become actively expressed in patients with several different neurodegenerative disorders and in animal models of the disorders (Lathe and Harris, 2009; Jeong et al., 2010; Muotri et al., 2010; Coufal et al., 2011; Douville et al., 2011; Kaneko et al., 2011; Li et al., 2012; Tan et al., 2012). In the case of amyotrophic lateral sclerosis (Lou Gehrig's disease) and frontotemporal lobar degeneration, there is a link between transposon regulation and TAR DNA-binding protein-43 (TDP-43), which is one of the central players in the disease pathology ( $\mathrm{Li}$ et al., 2012).

TDP-43 is an aggregation prone protein that plays a key role in a suite of neurodegenerative disorders (Cohen et al., 2011), including amyotrophic lateral sclerosis (Lou Gehrig's disease) and frontotemporal lobar degeneration, which is the second leading cause of dementia before the age of 65. TDP-43 is a multifunctional RNA-binding protein with roles in many aspects of RNA 
regulation (Buratti and Baralle, 2010). Although it is not clear how TDP-43 malfunction kills neurons, many downstream impacts of TDP- 43 proteinopathy have been elucidated. A series of studies made use of deep sequencing to identify RNA targets of TDP-43 in mouse, rat, and human neurons and characterized changes in transcriptional profiles in response to genetic manipulation of TDP-43 in mouse (Shan et al., 2010; Polymenidou et al., 2011; Sephton et al., 2011; Tollervey et al., 2011). Together, this literature identified thousands of RNA targets of TDP-43. Typically, TDP-43 binds to a UG-rich motif in long introncontaining transcripts. Many additional transcripts were found to be mis-regulated in mouse models of TDP-43 proteinopathy. Because of the difficulty of mapping repetitive reads (Treangen and Salzberg, 2012), each of these deep sequencing studies used analyses that focused on single copy annotated genes and excluded repetitive sequences, such as those that typically derive from transposons. More recently, new algorithms for analyzing multiple alignments of short sequence reads have been developed (Ji et al., 2011; Li et al., 2012), permitting a systematic analysis of transposon transcripts within these datasets. This analysis uncovered extensive binding of TDP-43 to RNA sequences derived from many transposons, including LINE, SINE, and LTR retrotransposons ( $\mathrm{Li}$ et al., 2012). In a dataset that compared TDP-43 targets from healthy control cortex and cortical tissue from frontotemporal lobar degeneration patients (Tollervey et al., 2011), the binding between TDP-43 and its transposon targets was selectively and dramatically reduced (Li et al., 2012). Moreover, examination of transposon sequences (Li et al., 2012) in RNA-seq datasets from mice with disruptions of normal TDP-43 function (Shan et al., 2010; Polymenidou et al., 2011) revealed upregulation of many of the LINE, SINE, and LTR-retrotransposon transcripts to which TDP-43 normally binds. Taken as a whole, this meta-analysis raises the possibility that TDP-43 normally plays a protective role by binding to and silencing transposon transcripts.

The cellular mechanisms that lead to transposon activation in the brain during aging and with some neurodegenerative disorders are not understood. Furthermore, it is not known whether transposon expression is a cause or a consequence of aging or of neurodegenerative disease. Nevertheless, studies of dysfunctional activation of transposons during aging and neurodegeneration raise the provocative hypothesis that normally silenced transposons can become "awakened" (i.e., unsilenced, leading to increased expression and mobilization) in the brain during aging or with disease.

\section{Activation of transposable elements in an animal model of PTSD and human alcoholism}

There is much emerging evidence for the role of retrotransposons in regulation of brain function in health and disease. The availability of whole-genome sequences of multiple species (Adams et al., 2000; Lander et al., 2001; Waterston et al., 2002; Gibbs et al., 2004; Nellaker et al., 2012) and recent genome-wide projects, such as ENCODE (Dunham et al., 2012), greatly accelerated these research efforts, as information about the genomic location, diversity, and regulation of retrotransposons became available. Studies that use whole-genome approaches (e.g., microarray gene expression profiling and next-generation sequencing) can benefit tremendously from these new data on the function and localization of retrotransposons. A large portion of transcribed sequences (transcripts) used by these technologies are "unannotated" (i.e., corresponding to genomic locations with no proteincoding genes or repeated sequences, such as ribosomal proteins or retrotransposons). Most genomic studies usually discard these sequences from the analysis and focus on a small number of known protein-coding genes. An alternative is to take a systems genomics approach, focusing on the regulation of the transcriptome as a whole, including both coding and noncoding regions (Oldham et al., 2008; Ward and Kellis, 2012). One of the first coordinated efforts to investigate the role of TEs in the brain using a genome-wide approach was the study of central mechanisms underlying stress-enhanced fear learning (SEFL) in rats, which is an accepted model of PTSD in humans (Rau and Fanselow, 2009; Ponomarev et al., 2010). PTSD is a brain disorder that may develop after a person is exposed to one or more traumatic events. It is characterized by an exaggerated emotional reaction to mild stressors, and people who have PTSD may feel stressed or frightened even when they are no longer in danger. In the SEFL model, rats preexposed to a severe stressor of 15 foot shocks in one environment showed an enhanced freezing response to a single "reminder" foot shock in a second environment (Rau et al., 2005). This SEFL is similar to the disproportionately strong responses that PTSD patients show to reminders of the stressor. Gene expression profiles in the amygdala of SEFL rats were examined 3 weeks after the exposure to 15 foot shocks using Illumina microarrays. Using a clustering algorithm, several modules of genes coregulated by stress were detected, which corresponded to various functional and structural groups in the brain, including genes coexpressed in neurons and astrocytes. This finding suggested specific roles for these cell classes in the development of SEFL (Ponomarev et al., 2010).

One surprising finding was a statistically distinct module containing tightly coregulated transcripts with no annotations. Illumina probes were mapped to the rat genome using a combination of the UCSC Genome Browser and the RepeatMasker program that identifies the location of genomic repeats, including retrotransposons and showed that the majority of the unannotated microarray probes mapped to multiple locations in the genome that corresponded to LINE-1 retrotransposons. Furthermore, all these transcripts were highly upregulated in the basolateral amygdala of the SEFL rats compared with controls, suggesting that a single stress exposure could result in a long-term activation of retrotransposons. Retrotransposons are normally silenced by epigenetic mechanisms, including DNA methylation and modifications of histone tails, but can be expressed when the epigenetic silencing is released (Slotkin and Martienssen, 2007). Therefore, these results suggested that the increased expression of retrotransposons in SEFL rats was the result of a "passive" release of chromatin-mediated gene silencing. Interestingly, it was recently shown that acute restraint stress in rats inhibited expression of several classes of retrotransposons in the hippocampus through increases in repressive histone $\mathrm{H} 3$ lysine 9 trimethylation (Hunter et al., 2012). Therefore, there may be dynamic and opposing regulation of different types of retrotransposons depending on the magnitude and duration of the stressor as well as the brain region where they are expressed.

In another recent study, gene expression profiling in postmortem human brains of alcoholics and control cases using Illumina microarrays was conducted (Ponomarev et al., 2012). Alcoholism is a serious health problem that causes a large economic and disease burden (Grant et al., 2004; Rehm et al., 2009). Understanding the mechanistic changes in human brain after years of alcohol abuse is critical to understanding the disease and developing therapeutics to fight it. Similar to the previous study (Ponomarev et al., 2010), a systems genomics approach to transcriptome profiling was conducted and generated a systematic view of brain alterations associated with alcohol abuse. One of the 
key components of this study was targeting differentially expressed retrotransposons in human alcoholic brain, including the central and basolateral amygdala and superior frontal cortex. Alignment of Illumina microarray probes to genomic retrotransposons using the RepeatMasker program showed that nearly 4000 probes could be mapped to one of three classes of retrotransposons (LINEs, SINEs, and LTRs) as well as DNA transposons. Gene clustering revealed that probes representing at least two TE classes (SINEs and LTR) were highly correlated (coregulated) across samples, forming several distinct gene modules. In addition, many probes mapped to several families of LTRcontaining TEs, and these LTR modules were upregulated in alcoholics. Interestingly, the only Illumina probe corresponding to a currently "active" LINE-1 family, L1HS (ILMN_2291619) was also highly upregulated in alcoholic brain. Examination of DNA methylation at the LTR regions showed that, in alcoholics, these regions were less methylated, which is mechanistically consistent with the activation of these transposons because they are suppressed by methylation. This study showed that chronic alcohol abuse resulted in DNA hypomethylation and transcriptional activation of LTR-containing transposons and at least one family of LINE-1 TE.

Stress enhances alcohol drinking in animal models, and many alcoholics have had stressful events associated with their alcohol abuse (Becker et al., 2011; Sinha, 2012). Human alcoholism and PTSD are comorbid conditions, as many PTSD patients abuse alcohol (McCarthy and Petrakis, 2010). Based on the two studies described above and other literature, it can be concluded that stress and/or chronic alcohol may lead to transcriptional activation of TEs. Indeed, this is the first report suggesting that LTRcontaining TEs may play a functional role in alcoholism (Ponomarev et al., 2012). These TEs represent a class of ERVs, most of which are nonfunctional remnants of ancient retroviral infections (Moyes et al., 2007). However, many human ERVs have retained functional promoters and the potential to encode viral proteins. Activation of ERVs has been linked to chronic diseases, including cancer, multiple sclerosis, and autoimmune disorders (Balada et al., 2009). An ERV-encoded glycoprotein, syncytin, can directly activate microglia and astrocytes and produce neuroinflammation (Antony et al., 2004). Microglial activation can result in neuronal degeneration (Crews et al., 2011), and compounds secreted by syncytin-activated astrocytes can produce cytotoxicity to oligodendrocytes and myelin degeneration (Antony et al., 2004), which is consistent with pathologies observed in alcoholics (Harper et al., 2003; Pfefferbaum et al., 2009; Zahr et al., 2011). Based on recent evidence that alcoholinduced neuroimmune responses are critical factors in alcohol addiction (Crews et al., 2011), these studies propose a potential role for ERVs in neuroinflammation and brain pathophysiology of human alcoholism. However, it remains to be determined whether ERVs play a causal role because it is not known whether altered expression of ERVs results in the expression of viral proteins and the initiation of the immune response in brain.

In addition to understanding the functional role of TEs in brain function, utilization of the emerging knowledge about the epigenetic regulation of TEs will enable a complete picture of TE regulation and function (Xie et al., 2013). TEs are tightly controlled and silenced by epigenetic mechanisms, and their expression patterns can be used as markers of epigenetic modifications without directly measuring epigenetic marks. Furthermore, detecting certain epigenetic changes may lead to hypotheses about TE regulation. There is substantial evidence suggesting the importance of epigenetics in stress-related disorders, including
PTSD and alcoholism (Radley et al., 2011; Robison and Nestler, 2011), and this knowledge may be useful in better understanding the role of TEs in these conditions. In addition, many epigenetic therapeutics have been developed for non-CNS diseases. Therefore, epigenetic mechanisms could be targeted to alter the potentially deleterious effects of brain retrotransposons. Finally, examination of the effects of stress and alcohol on retrotransposons in additional regions of the brain is warranted. In particular, the hippocampus is an important target of stress and alcohol; both stress and alcohol decrease adult hippocampal neurogenesis (Dranovsky and Hen, 2006; Nixon, 2006). The majority of studies examining the function and expression of retrotransposons have been conducted in this region because neurogenesis in the hippocampus has been shown to substantially regulate the activity of retrotransposons (Muotri et al., 2005, 2009; Coufal et al., 2009; Muotri et al., 2010; Baillie et al., 2011).

\section{Conclusions and future directions}

The longstanding idea that neuronal genomes contain stable, unchanging DNA is now being challenged by mounting evidence that somatic retrotransposition occurs in neurons. This review has highlighted the evidence that retrotransposons, McClintock's "jumping genes," must now be considered as a viable source of genetic variability in the brain and in health and disease of the CNS. The advances in genomic technologies have enabled a deeper understanding of the role of retrotransposons in neuronal function and evolution. This is indeed an exciting time for what was once dismissed as genomic "parasites" or "selfish" entities of the genome.

The sheer abundance of retrotransposons in eukaroyotic genomes begs us to reconsider their role in biology and in neuroscience in particular. Altered retrotransposon expression or function appears to be associated with stress, alcohol, neurodegeneration, and aging. However, we need to better define the functional consequences of these retrotransposons, which could lead to novel treatment strategies for a multitude of psychiatric and neurological disorders.

Finally, the evolutionary significance of retrotransposons, especially in the evolution of brain function, is paramount in understanding why nature has produced such a biological mechanism. Cross-species analysis of the function of retrotransposons in the brain will undoubtedly provide clues to their origin and their potential as drivers of genomic innovation.

\section{References}

Adams MD, Celniker SE, Holt RA, Evans CA, Gocayne JD, Amanatides PG, Scherer SE, Li PW, Hoskins RA, Galle RF, George RA, Lewis SE, Richards S, Ashburner M, Henderson SN, Sutton GG, Wortman JR, Yandell MD, Zhang Q, Chen LX, et al. (2000) The genome sequence of Drosophila melanogaster. Science 287:2185-2195. CrossRef Medline

Antony JM, van Marle G, Opii W, Butterfield DA, Mallet F, Yong VW, Wallace JL, Deacon RM, Warren K, Power C (2004) Human endogenous retrovirus glycoprotein-mediated induction of redox reactants causes oligodendrocyte death and demyelination. Nat Neurosci 7:1088-1095. CrossRef Medline

Azevedo FA, Carvalho LR, Grinberg LT, Farfel JM, Ferretti RE, Leite RE, Jacob Filho W, Lent R, Herculano-Houzel S (2009) Equal numbers of neuronal and nonneuronal cells make the human brain an isometrically scaled-up primate brain. J Comp Neurol 513:532-541. CrossRef Medline

Baillie JK, Barnett MW, Upton KR, Gerhardt DJ, Richmond TA, De Sapio F, Brennan PM, Rizzu P, Smith S, Fell M, Talbot RT, Gustincich S, Freeman TC, Mattick JS, Hume DA, Heutink P, Carninci P, Jeddeloh JA, Faulkner GJ (2011) Somatic retrotransposition alters the genetic landscape of the human brain. Nature 479:534-537. CrossRef Medline

Balada E, Ordi-Ros J, Vilardell-Tarrés M (2009) Molecular mechanisms 
mediated by human endogenous retroviruses (HERVs) in autoimmunity. Rev Med Virol 19:273-286. CrossRef Medline

Barsoum E, Martinez P, Aström SU (2010) Alpha3, a transposable element that promotes host sexual reproduction. Genes Dev 24:33-44. CrossRef Medline

Batzer MA, Arcot SS, Phinney JW, Alegria-Hartman M, Kass DH, Milligan SM, Kimpton C, Gill P, Hochmeister M, Ioannou PA, Herrera RJ, Boudreau DA, Scheer WD, Keats BJ, Deininger PL, Stoneking M (1996) Genetic variation of recent Alu insertions in human populations. J Mol Evol 42:22-29. CrossRef Medline

Beck CR, Collier P, Macfarlane C, Malig M, Kidd JM, Eichler EE, Badge RM, Moran JV (2010) LINE-1 retrotransposition activity in human genomes. Cell 141:1159-1170. CrossRef Medline

Beck CR, Garcia-Perez JL, Badge RM, Moran JV (2011) LINE-1 elements in structural variation and disease. Annu Rev Genomics Hum Genet 12:187215. CrossRef Medline

Becker HC, Lopez MF, Doremus-Fitzwater TL (2011) Effects of stress on alcohol drinking: a review of animal studies. Psychopharmacology (Berl) 218:131-156. CrossRef Medline

Biémont C (2010) A brief history of the status of transposable elements: from junk DNA to major players in evolution. Genetics 186:1085-1093. CrossRef Medline

Boeke JD, Garfinkel DJ, Styles CA, Fink GR (1985) Ty elements transpose through an RNA intermediate. Cell 40:491-500. CrossRef Medline

Britten RJ, Kohne DE (1968) Repeated sequences in DNA: hundreds of thousands of copies of DNA sequences have been incorporated into the genomes of higher organisms. Science 161:529-540. CrossRef Medline

Britten RJ, Stout DB, Davidson EH (1989) The current source of human Alu retroposons is a conserved gene shared with Old World monkey. Proc Natl Acad Sci U S A 86:3718-3722. CrossRef Medline

Buratti E, Baralle FE (2010) The multiple roles of TDP-43 in pre-mRNA processing and gene expression regulation. RNA Biol 7:420-429. CrossRef Medline

Carroll SB (2008) Evo-devo and an expanding evolutionary synthesis: a genetic theory of morphological evolution. Cell 134:25-36. CrossRef Medline

Cavalier-Smith T (1991) Intron phylogeny: a new hypothesis. Trends Genet 7:145-148. CrossRef Medline

Chen Y, Pane A, Schüpbach T (2007) Cutoff and aubergine mutations result in retrotransposon upregulation and checkpoint activation in Drosophila. Curr Biol 17:637-642. CrossRef Medline

Chung WJ, Okamura K, Martin R, Lai EC (2008) Endogenous RNA interference provides a somatic defense against Drosophila transposons. Curr Biol 18:795-802. CrossRef Medline

Cohen TJ, Lee VM, Trojanowski JQ (2011) TDP-43 functions and pathogenic mechanisms implicated in TDP-43 proteinopathies. Trends Mol Med 17:659-667. CrossRef Medline

Coufal NG, Garcia-Perez JL, Peng GE, Yeo GW, Mu Y, Lovci MT, Morell M, O'Shea KS, Moran JV, Gage FH (2009) L1 retrotransposition in human neural progenitor cells. Nature 460:1127-1131. CrossRef Medline

Coufal NG, Garcia-Perez JL, Peng GE, Marchetto MC, Muotri AR, Mu Y, Carson CT, Macia A, Moran JV, Gage FH (2011) Ataxia telangiectasia mutated (ATM) modulates long interspersed element-1 (L1) retrotransposition in human neural stem cells. Proc Natl Acad Sci U S A 108:2038220387. CrossRef Medline

Crews FT, Zou J, Qin L (2011) Induction of innate immune genes in brain create the neurobiology of addiction. Brain Behav Immun 25 [Suppl 1]: S4-S12.

Czech B, Hannon GJ (2011) Small RNA sorting: matchmaking for Argonautes. Nat Rev Genet 12:19-31. CrossRef Medline

Czech B, Malone CD, Zhou R, Stark A, Schlingeheyde C, Dus M, Perrimon N, Kellis M, Wohlschlegel JA, Sachidanandam R, Hannon GJ, Brennecke J (2008) An endogenous small interfering RNA pathway in Drosophila. Nature 453:798-802. CrossRef Medline

Daniels GR, Deininger PL (1985) Repeat sequence families derived from mammalian tRNA genes. Nature 317:819-822. CrossRef Medline

Dewannieux M, Esnault C, Heidmann T (2003) LINE-mediated retrotransposition of marked Alu sequences. Nat Genet 35:41-48. CrossRef Medline

Djebali S, Davis CA, Merkel A, Dobin A, Lassmann T, Mortazavi A, Tanzer A, Lagarde J, Lin W, Schlesinger F, Xue C, Marinov GK, Khatun J, Williams BA, Zaleski C, Rozowsky J, Röder M, Kokocinski F, Abdelhamid RF, Alioto T, et al. (2012) Landscape of transcription in human cells. Nature 489:101-108. CrossRef Medline

Dombroski BA, Mathias SL, Nanthakumar E, Scott AF, Kazazian HH Jr
(1991) Isolation of an active human transposable element. Science 254: 1805-1808. CrossRef Medline

Douville R, Liu J, Rothstein J, Nath A (2011) Identification of active loci of a human endogenous retrovirus in neurons of patients with amyotrophic lateral sclerosis. Ann Neurol 69:141-151. CrossRef Medline

Dranovsky A, Hen R (2006) Hippocampal neurogenesis: regulation by stress and antidepressants. Biol Psychiatry 59:1136-1143. CrossRef Medline

Dunham I, Bernstein BE, Birney E, Dunham I, Green ED, Gunter C, Snyder M (2012) An integrated encyclopedia of DNA elements in the human genome. Nature 489:57-74. CrossRef Medline

Eickbush TH, Burke WD, Eickbush DG, Lathe WC 3rd (1997) Evolution of R1 and R2 in the rDNA units of the genus Drosophila. Genetica 100:49-61. CrossRef Medline

Emera D, Wagner GP (2012) Transformation of a transposon into a derived prolactin promoter with function during human pregnancy. Proc Natl Acad Sci U S A 109:11246-11251. CrossRef Medline

Eriksson PS, Perfilieva E, Björk-Eriksson T, Alborn AM, Nordborg C, Peterson DA, Gage FH (1998) Neurogenesis in the adult human hippocampus. Nat Med 4:1313-1317. CrossRef Medline

Esnault C, Maestre J, Heidmann T (2000) Human LINE retrotransposons generate processed pseudogenes. Nat Genet 24:363-367. CrossRef Medline

Evrony GD, Cai X, Lee E, Hills LB, Elhosary PC, Lehmann HS, Parker JJ, Atabay KD, Gilmore EC, Poduri A, Park PJ, Walsh CA (2012) Singleneuron sequencing analysis of L1 retrotransposition and somatic mutation in the human brain. Cell 151:483-496. CrossRef Medline

Ewing AD, Kazazian HH Jr (2010) High-throughput sequencing reveals extensive variation in human-specific L1 content in individual human genomes. Genome Res 20:1262-1270. CrossRef Medline

Faulkner GJ, Kimura Y, Daub CO, Wani S, Plessy C, Irvine KM, Schroder K, Cloonan N, Steptoe AL, Lassmann T, Waki K, Hornig N, Arakawa T, Takahashi H, Kawai J, Forrest AR, Suzuki H, Hayashizaki Y, Hume DA, Orlando V, et al. (2009) The regulated retrotransposon transcriptome of mammalian cells. Nat Genet 41:563-571. CrossRef Medline

Feschotte C (2008) Transposable elements and the evolution of regulatory networks. Nat Rev Genet 9:397-405. CrossRef Medline

Fraga MF, Ballestar E, Paz MF, Ropero S, Setien F, Ballestar ML, Heine-Suñer D, Cigudosa JC, Urioste M, Benitez J, Boix-Chornet M, Sanchez-Aguilera A, Ling C, Carlsson E, Poulsen P, Vaag A, Stephan Z, Spector TD, Wu YZ, Plass C, et al. (2005) Epigenetic differences arise during the lifetime of monozygotic twins. Proc Natl Acad Sci U S A 102:10604-10609. CrossRef Medline

Garcia-Perez JL, Morell M, Scheys JO, Kulpa DA, Morell S, Carter CC, Hammer GD, Collins KL, O'Shea KS, Menendez P, Moran JV (2010) Epigenetic silencing of engineered L1 retrotransposition events in human embryonic carcinoma cells. Nature 466:769-773. CrossRef Medline

Ghildiyal M, Zamore PD (2009) Small silencing RNAs: an expanding universe. Nat Rev Genet 10:94-108. CrossRef Medline

Ghildiyal M, Seitz H, Horwich MD, Li C, Du T, Lee S, Xu J, Kittler EL, Zapp ML, Weng Z, Zamore PD (2008) Endogenous siRNAs derived from transposons and mRNAs in Drosophila somatic cells. Science 320:10771081. CrossRef Medline

Gibbs RA, Weinstock GM, Metzker ML, Muzny DM, Sodergren EJ, Scherer S, Scott G, Steffen D, Worley KC, Burch PE, Okwuonu G, Hines S, Lewis L, DeRamo C, Delgado O, Dugan-Rocha S, Miner G, Morgan M, Hawes A, Gill $\mathrm{R}$, et al. (2004) Genome sequence of the Brown Norway rat yields insights into mammalian evolution. Nature 428:493-521. CrossRef Medline

Grant BF, Dawson DA, Stinson FS, Chou SP, Dufour MC, Pickering RP (2004) The 12-month prevalence and trends in DSM-IV alcohol abuse and dependence: United States, 1991-1992 and 2001-2002. Drug Alcohol Depend 74:223-234. CrossRef Medline

Graves JA (2010) Review: sex chromosome evolution and the expression of sex-specific genes in the placenta. Placenta 31 [Suppl]:S27-S32.

Grimaldi G, Singer MF (1982) A monkey Alu sequence is flanked by 13-base pair direct repeats by an interrupted alpha-satellite DNA sequence. Proc Natl Acad Sci U S A 79:1497-1500. CrossRef Medline

Guo JH, Huang Q, Studholme DJ, Wu CQ, Zhao Z (2005) Transcriptomic analyses support the similarity of gene expression between brain and testis in human as well as mouse. Cytogenet Genome Res 111:107-109. CrossRef Medline

Guo J, Zhu P, Wu C, Yu L, Zhao S, Gu X (2003) In silico analysis indicates a similar gene expression pattern between human brain and testis. Cytogenet Genome Res 103:58-62. CrossRef Medline 
Hancks DC, Mandal PK, Cheung LE, Kazazian HH Jr (2012) The minimal active human SVA retrotransposon requires only the $5^{\prime}$-hexamer and Alu-like domains. Mol Cell Biol 32:4718-4726. CrossRef Medline

Harper C, Dixon G, Sheedy D, Garrick T (2003) Neuropathological alterations in alcoholic brains: studies arising from the New South Wales Tissue Resource Centre. Prog Neuropsychopharmacol Biol Psychiatry 27:951961. CrossRef Medline

Heard E, Tishkoff S, Todd JA, Vidal M, Wagner GP, Wang J, Weigel D, Young $R$ (2010) Ten years of genetics and genomics: what have we achieved and where are we heading? Nat Rev Genet 11:723-733. CrossRef Medline

Henn BM, Cavalli-Sforza LL, Feldman MW (2012) The great human expansion. Proc Natl Acad Sci U S A 109:17758-17764. CrossRef Medline

Hickey DA (1982) Selfish DNA: a sexually-transmitted nuclear parasite. Genetics 101:519-531. Medline

Houle D, Nuzhdin SV (2004) Mutation accumulation and the effect of copia insertions in Drosophila melanogaster. Genet Res 83:7-18. CrossRef Medline

Huang CR, Schneider AM, Lu Y, Niranjan T, Shen P, Robinson MA, Steranka JP, Valle D, Civin CI, Wang T, Wheelan SJ, Ji H, Boeke JD, Burns KH (2010) Mobile interspersed repeats are major structural variants in the human genome. Cell 141:1171-1182. CrossRef Medline

Hunter RG, Murakami G, Dewell S, Seligsohn M, Baker ME, Datson NA, McEwen BS, Pfaff DW (2012) Acute stress and hippocampal histone H3 lysine 9 trimethylation, a retrotransposon silencing response. Proc Natl Acad Sci U S A 109:17657-17662. CrossRef Medline

Iskow RC, McCabe MT, Mills RE, Torene S, Pittard WS, Neuwald AF, Van Meir EG, Vertino PM, Devine SE (2010) Natural mutagenesis of human genomes by endogenous retrotransposons. Cell 141:1253-1261. CrossRef Medline

Jablonka E, Lamb MJ (2007) Précis of evolution in four dimensions. Behav Brain Sci 30:353-365; discussion 365-389. Medline

Jensen S, Cavarec L, Gassama MP, Heidmann T (1995) Defective I elements introduced into Drosophila as transgenes can regulate reactivity and prevent I-R hybrid dysgenesis. Mol Gen Genet 248:381-390. CrossRef Medline

Jensen S, Gassama MP, Heidmann T (1999) Taming of transposable elements by homology-dependent gene silencing. Nat Genet 21:209-212. CrossRef Medline

Jeong BH, Lee YJ, Carp RI, Kim YS (2010) The prevalence of human endogenous retroviruses in cerebrospinal fluids from patients with sporadic Creutzfeldt-Jakob disease. J Clin Virol 47:136-142. CrossRef Medline

Ji Y, Xu Y, Zhang Q, Tsui KW, Yuan Y, Norris C Jr, Liang S, Liang H (2011) BM-map: Bayesian mapping of multireads for next-generation sequencing data. Biometrics 67:1215-1224. CrossRef Medline

Kajikawa M, Okada N (2002) LINEs mobilize SINEs in the eel through a shared 3' sequence. Cell 111:433-444. CrossRef Medline

Kaneko H, Dridi S, Tarallo V, Gelfand BD, Fowler BJ, Cho WG, Kleinman ME, Ponicsan SL, Hauswirth WW, Chiodo VA, Karikó K, Yoo JW, Lee DK, Hadziahmetovic M, Song Y, Misra S, Chaudhuri G, Buaas FW, Braun RE, Hinton DR, et al. (2011) DICER1 deficit induces Alu RNA toxicity in age-related macular degeneration. Nature 471:325-330. CrossRef Medline

Kawamura Y, Saito K, Kin T, Ono Y, Asai K, Sunohara T, Okada TN, Siomi MC, Siomi H (2008) Drosophila endogenous small RNAs bind to Argonaute 2 in somatic cells. Nature 453:793-797. CrossRef Medline

Kazazian HH Jr, Wong C, Youssoufian H, Scott AF, Phillips DG, Antonarakis SE (1988) Haemophilia A resulting from de novo insertion of L1 sequences represents a novel mechanism for mutation in man. Nature 332: 164-166. CrossRef Medline

Klattenhoff C, Bratu DP, McGinnis-Schultz N, Koppetsch BS, Cook HA, Theurkauf WE (2007) Drosophila rasiRNA pathway mutations disrupt embryonic axis specification through activation of an ATR/Chk2 DNA damage response. Dev Cell 12:45-55. CrossRef Medline

Lander ES, Linton LM, Birren B, Nusbaum C, Zody MC, Baldwin J, Devon K, Dewar K, Doyle M, FitzHugh W, Funke R, Gage D, Harris K, Heaford A, Howland J, Kann L, Lehoczky J, LeVine R, McEwan P, McKernan K, et al. (2001) Initial sequencing and analysis of the human genome. Nature 409:860-921. CrossRef Medline

Lathe R, Harris A (2009) Differential display detects host nucleic acid motifs altered in scrapie-infected brain. J Mol Biol 392:813-822. CrossRef Medline
Levin HL, Moran JV (2011) Dynamic interactions between transposable elements and their hosts. Nat Rev Genet 12:615-627. CrossRef Medline

Li W, Jin Y, Prazak L, Hammell M, Dubnau J (2012) Transposable elements in TDP-43-mediated neurodegenerative disorders. PLoS One 7:e44099. CrossRef Medline

Li W, Prazak L, Chatterjee N, Grüninger S, Krug L, Theodorou D, Dubnau J (2013) Activation of transposable elements during aging and neuronal decline in Drosophila. Nat Neurosci 16:529-531. CrossRef Medline

Lupski JR (2013) Genetics. Genome mosaicism: one human, multiple genomes. Science 341:358-359. CrossRef Medline

Malone CD, Hannon GJ (2009) Molecular evolution of piRNA and transposon control pathways in Drosophila. Cold Spring Harb Symp Quant Biol 74:225-234. CrossRef Medline

Manolio TA, Collins FS, Cox NJ, Goldstein DB, Hindorff LA, Hunter DJ, McCarthy MI, Ramos EM, Cardon LR, Chakravarti A, Cho JH, Guttmacher AE, Kong A, Kruglyak L, Mardis E, Rotimi CN, Slatkin M, Valle D, Whittemore AS, Boehnke M, et al. (2009) Finding the missing heritability of complex diseases. Nature 461:747-753. CrossRef Medline

Mattick JS, Taft RJ, Faulkner GJ (2010) A global view of genomic information: moving beyond the gene and the master regulator. Trends Genet 26:21-28. CrossRef Medline

McCarthy E, Petrakis I (2010) Epidemiology and management of alcohol dependence in individuals with post-traumatic stress disorder. CNS Drugs 24:997-1007. CrossRef Medline

McClintock B (1951) Chromosome organization and genic expression. Cold Spring Harb Symp Quant Biol 16:13-47. CrossRef Medline

McClintock B (1984) The significance of responses of the genome to challenge. Science 226:792-801. CrossRef Medline

Moran JV, Holmes SE, Naas TP, DeBerardinis RJ, Boeke JD, Kazazian HH Jr (1996) High frequency retrotransposition in cultured mammalian cells. Cell 87:917-927. CrossRef Medline

Moran JV, DeBerardinis RJ, Kazazian HH Jr (1999) Exon shuffling by L1 retrotransposition. Science 283:1530-1534. CrossRef Medline

Moss WN, Eickbush DG, Lopez MJ, Eickbush TH, Turner DH (2011) The R2 retrotransposon RNA families. RNA Biol 8:714-718. CrossRef Medline

Moyes D, Griffiths DJ, Venables PJ (2007) Insertional polymorphisms: a new lease of life for endogenous retroviruses in human disease. Trends Genet 23:326-333. CrossRef Medline

Mukamel Z, Tanay A (2013) Hypomethylation marks enhancers within transposable elements. Nat Genet 45:717-718. CrossRef Medline

Muotri AR, Chu VT, Marchetto MC, Deng W, Moran JV, Gage FH (2005) Somatic mosaicism in neuronal precursor cells mediated by L1 retrotransposition. Nature 435:903-910. CrossRef Medline

Muotri AR, Zhao C, Marchetto MC, Gage FH (2009) Environmental influence on L1 retrotransposons in the adult hippocampus. Hippocampus 19:1002-1007. CrossRef Medline

Muotri AR, Marchetto MC, Coufal NG, Oefner R, Yeo G, Nakashima K, Gage FH (2010) L1 retrotransposition in neurons is modulated by MeCP2. Nature 468:443-446. CrossRef Medline

Nakamura TM, Cech TR (1998) Reversing time: origin of telomerase. Cell 92:587-590. CrossRef Medline

Navarro C, Bullock S, Lehmann R (2009) Altered dynein-dependent transport in piRNA pathway mutants. Proc Natl Acad Sci U S A 106:96919696. CrossRef Medline

Nellåker C, Keane TM, Yalcin B, Wong K, Agam A, Belgard TG, Flint J, Adams DJ, Frankel WN, Ponting CP (2012) The genomic landscape shaped by selection on transposable elements across 18 mouse strains. Genome Biol 13:R45. CrossRef Medline

Nixon K (2006) Alcohol and adult neurogenesis: roles in neurodegeneration and recovery in chronic alcoholism. Hippocampus 16:287-295. CrossRef Medline

Ohno S (1972) So much "junk" DNA in our genome. Brookhaven Symp Biol 23:366-370. Medline

Oldham MC, Konopka G, Iwamoto K, Langfelder P, Kato T, Horvath S, Geschwind DH (2008) Functional organization of the transcriptome in human brain. Nat Neurosci 11:1271-1282. CrossRef Medline

Orgel LE, Crick FH (1980) Selfish DNA: the ultimate parasite. Nature 284: 604-607. CrossRef Medline

Ostertag EM, Prak ET, DeBerardinis RJ, Moran JV, Kazazian HH Jr (2000) Determination of L1 retrotransposition kinetics in cultured cells. Nucleic Acids Res 28:1418-1423. CrossRef Medline 
Perrat PN, DasGupta S, Wang J, Theurkauf W, Weng Z, Rosbash M, Waddell S (2013) Transposition-driven genomic heterogeneity in the Drosophila brain. Science 340:91-95. CrossRef Medline

Pfefferbaum A, Rosenbloom M, Rohlfing T, Sullivan EV (2009) Degradation of association and projection white matter systems in alcoholism detected with quantitative fiber tracking. Biol Psychiatry 65:680-690. CrossRef Medline

Pignatelli PM, Mackay TF (1989) Hybrid dysgenesis-induced response to selection in Drosophila melanogaster. Genet Res 54:183-195. CrossRef Medline

Polymenidou M, Lagier-Tourenne C, Hutt KR, Huelga SC, Moran J, Liang TY, Ling SC, Sun E, Wancewicz E, Mazur C, Kordasiewicz H, Sedaghat Y, Donohue JP, Shiue L, Bennett CF, Yeo GW, Cleveland DW (2011) Long pre-mRNA depletion and RNA missplicing contribute to neuronal vulnerability from loss of TDP-43. Nat Neurosci 14:459-468. CrossRef Medline

Ponomarev I, Rau V, Eger EI, Harris RA, Fanselow MS (2010) Amygdala transcriptome and cellular mechanisms underlying stress-enhanced fear learning in a rat model of posttraumatic stress disorder. Neuropsychopharmacology 35:1402-1411. CrossRef Medline

Ponomarev I, Wang S, Zhang L, Harris RA, Mayfield RD (2012) Gene coexpression networks in human brain identify epigenetic modifications in alcohol dependence. J Neurosci 32:1884-1897. CrossRef Medline

Radley JJ, Kabbaj M, Jacobson L, Heydendael W, Yehuda R, Herman JP (2011) Stress risk factors and stress-related pathology: neuroplasticity, epigenetics and endophenotypes. Stress 14:481-497. CrossRef Medline

Raiz J, Damert A, Chira S, Held U, Klawitter S, Hamdorf M, Löwer J, Strätling WH, Löwer R, Schumann GG (2012) The non-autonomous retrotransposon SVA is trans-mobilized by the human LINE-1 protein machinery. Nucleic Acids Res 40:1666-1683. CrossRef Medline

Rau V, Fanselow MS (2009) Exposure to a stressor produces a long lasting enhancement of fear learning in rats. Stress 12:125-133. CrossRef Medline

Rau V, DeCola JP, Fanselow MS (2005) Stress-induced enhancement of fear learning: an animal model of posttraumatic stress disorder. Neurosci Biobehav Rev 29:1207-1223. CrossRef Medline

Rehm J, Mathers C, Popova S, Thavorncharoensap M, Teerawattananon Y, Patra J (2009) Global burden of disease and injury and economic cost attributable to alcohol use and alcohol-use disorders. Lancet 373:22232233. CrossRef Medline

Robison AJ, Nestler EJ (2011) Transcriptional and epigenetic mechanisms of addiction. Nat Rev Neurosci 12:623-637. CrossRef Medline

Sephton CF, Cenik C, Kucukural A, Dammer EB, Cenik B, Han Y, Dewey CM, Roth FP, Herz J, Peng J, Moore MJ, Yu G (2011) Identification of neuronal RNA targets of TDP-43-containing ribonucleoprotein complexes. J Biol Chem 286:1204-1215. CrossRef Medline

Shan X, Chiang PM, Price DL, Wong PC (2010) Altered distributions of Gemini of coiled bodies and mitochondria in motor neurons of TDP-43 transgenic mice. Proc Natl Acad Sci U S A 107:16325-16330. CrossRef Medline

Sheen F, Lim JK, Simmons MJ (1993) Genetic instability in Drosophila melanogaster mediated by hobo transposable elements. Genetics 133: 315-334. Medline

Singer T, McConnell MJ, Marchetto MC, Coufal NG, Gage FH (2010) LINE-1 retrotransposons: mediators of somatic variation in neuronal genomes? Trends Neurosci 33:345-354. CrossRef Medline

Sinha R (2012) How does stress lead to risk of alcohol relapse? Alcohol Res 34:432-440. Medline

Slotkin RK, Martienssen R (2007) Transposable elements and the epigenetic regulation of the genome. Nat Rev Genet 8:272-285. CrossRef Medline

Solyom S, Ewing AD, Rahrmann EP, Doucet T, Nelson HH, Burns MB, Harris RS, Sigmon DF, Casella A, Erlanger B, Wheelan S, Upton KR, Shukla R, Faulkner GJ, Largaespada DA, Kazazian HH Jr (2012) Extensive somatic L1 retrotransposition in colorectal tumors. Genome Res 22: 2328-2338. CrossRef Medline

Tan H, Qurashi A, Poidevin M, Nelson DL, Li H, Jin P (2012) Retrotransposon activation contributes to fragile $\mathrm{X}$ premutation rCGG-mediated neurodegeneration. Hum Mol Genet 21:57-65. CrossRef Medline

Tanda S, Corces VG (1991) Retrotransposon-induced overexpression of a homeobox gene causes defects in eye morphogenesis in Drosophila. EMBO J 10:407-417. Medline
Thomas CA, Paquola AC, Muotri AR (2012) LINE-1 retrotransposition in the nervous system. Annu Rev Cell Dev Biol 28:555-573. CrossRef Medline

Thurman RE, Rynes E, Humbert R, Vierstra J, Maurano MT, Haugen E, Sheffield NC, Stergachis AB, Wang H, Vernot B, Garg K, John S, Sandstrom R, Bates D, Boatman L, Canfield TK, Diegel M, Dunn D, Ebersol AK, Frum T, et al. (2012) The accessible chromatin landscape of the human genome. Nature 489:75-82. CrossRef Medline

Tollervey JR, Curk T, Rogelj B, Briese M, Cereda M, Kayikci M, König J, Hortobágyi T, Nishimura AL, Zupunski V, Patani R, Chandran S, Rot G, Zupan B, Shaw CE, Ule J (2011) Characterizing the RNA targets and position-dependent splicing regulation by TDP-43. Nat Neurosci 14:452458. CrossRef Medline

Treangen TJ, Salzberg SL (2012) Repetitive DNA and next-generation sequencing: computational challenges and solutions. Nat Rev Genet 13:3646. CrossRef Medline

Upton KR, Baillie JK, Faulkner GJ (2011) Is somatic retrotransposition a parasitic or symbiotic phenomenon? Mob Genet Elements 1:279-282. CrossRef Medline

Wagner GP, Zhang J (2011) The pleiotropic structure of the genotypephenotype map: the evolvability of complex organisms. Nat Rev Genet 12:204-213. CrossRef Medline

Wanichnopparat W, Suwanwongse K, Pin-On P, Aporntewan C, Mutirangura A (2013) Genes associated with the cis-regulatory functions of intragenic LINE-1 elements. BMC Genomics 14:205. CrossRef Medline

Ward LD, Kellis M (2012) Interpreting noncoding genetic variation in complex traits and human disease. Nat Biotechnol 30:1095-1106. CrossRef Medline

Waterston RH, Lindblad-Toh K, Birney E, Rogers J, Abril JF, Agarwal P, Agarwala R, Ainscough R, Alexandersson M, An P, Antonarakis SE, Attwood J, Baertsch R, Bailey J, Barlow K, Beck S, Berry E, Birren B, Bloom $\mathrm{T}$, Bork P, et al. (2002) Initial sequencing and comparative analysis of the mouse genome. Nature 420:520-562. CrossRef Medline

Wei W, Gilbert N, Ooi SL, Lawler JF, Ostertag EM, Kazazian HH, Boeke JD, Moran JV (2001) Human L1 retrotransposition: cis preference versus trans complementation. Mol Cell Biol 21:1429-1439. CrossRef Medline

Whitelaw E, Martin DI (2001) Retrotransposons as epigenetic mediators of phenotypic variation in mammals. Nat Genet 27:361-365. CrossRef Medline

Wilda M, Bächner D, Zechner U, Kehrer-Sawatzki H, Vogel W, Hameister H (2000) Do the constraints of human speciation cause expression of the same set of genes in brain, testis, and placenta? Cytogenet Cell Genet 91:300-302. CrossRef Medline

Witherspoon DJ, Wooding S, Rogers AR, Marchani EE, Watkins WS, Batzer MA, Jorde LB (2007) Genetic similarities within and between human populations. Genetics 176:351-359. CrossRef Medline

Xie M, Hong C, Zhang B, Lowdon RF, Xing X, Li D, Zhou X, Lee HJ, Maire CL, Ligon KL, Gascard P, Sigaroudinia M, Tlsty TD, Kadlecek T, Weiss A, O'Geen H, Farnham PJ, Madden PA, Mungall AJ, Tam A, et al. (2013) DNA hypomethylation within specific transposable element families associates with tissue-specific enhancer landscape. Nat Genet 45:836-841. CrossRef Medline

Xiong Y, Eickbush TH (1988a) The site-specific ribosomal DNA insertion element R1Bm belongs to a class of non-long-terminal-repeat retrotransposons. Mol Cell Biol 8:114-123. Medline

Xiong YE, Eickbush TH (1988b) Functional expression of a sequencespecific endonuclease encoded by the retrotransposon R2Bm. Cell 55: 235-246. CrossRef Medline

Xiong Y, Eickbush TH (1990) Origin and evolution of retroelements based upon their reverse transcriptase sequences. EMBO J 9:3353-3362. Medline

Zahr NM, Kaufman KL, Harper CG (2011) Clinical and pathological features of alcohol-related brain damage. Nat Rev Neurol 7:284-294. CrossRef Medline

Zhang L, Rong YS (2012) Retrotransposons at Drosophila telomeres: host domestication of a selfish element for the maintenance of genome integrity. Biochim Biophys Acta 1819:771-775. CrossRef Medline

Zimmerly S, Guo H, Perlman PS, Lambowitz AM (1995) Group II intron mobility occurs by target DNA-primed reverse transcription. Cell 82 : 545-554. CrossRef Medline 